\section{Trakya Eğitim Dergisi}

Cilt 10, Sayı 3

Eylül 2020, 881-896

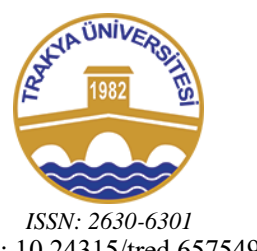

Doi: $10.24315 /$ tred.657549

Araştırma Makalesi

\section{Trakya Journal of Education}

Volume 10, Issue 3

September 2020, 881-896

Yayına Kabul Tarihi:29.05.2020

Research Article

\title{
Dönüşüm Geometrisi Alt Öğrenme Alanındaki Program Değişikliğinin Uygunluğunun Öğretmenler Açısından İncelenmesi ${ }^{1}$
}

\section{Investigation of The Conformity of Program Change in Transformation Geometry Sub-Learning in Terms of Teachers}

\section{Züleyha YILDIRIM YAKAR}

ÖZ: Bu çalışmanın amacı, matematik öğretmenlerinin 2018 ortaokul matematik dersi öğretim programında dönüşüm geometrisi alt öğrenme alanında yapılan değişikliklere ilişkin görüşlerini ve bu konudaki bilgi düzeylerini incelemektir. Betimsel tarama modelinin kullanıldığı araştırmanın katılımcılarını dört devlet ortaokulunda görev yapmakta olan yirmi matematik öğretmeni oluşturmaktadır. Öğretmenlerin dönüşüm geometrisi konusunda yapılan program değişikliğiyle ilgili düşüncelerini belirlemek için araştırmacı tarafindan hazırlanan ve üç açık uçlu sorudan oluşan yarı yapılandırılmış görüşme formu kullanılmıştır. Öğretmenlerin dönüşüm geometrisi konusundaki bilgi düzeylerinin incelenmesi amaciyla ise dört açık uçlu sorudan oluşan bir dönüşüm geometrisi ölçme aracı (DGÖA) kullanılmıştır. $\mathrm{Bu}$ ölçme aracında yansıma ve dönme dönüşümleriyle ilgili 2 şer soru yer almaktadır. Yarı yapılandırılmış görüşme formundan elde edilen verilerin analizinde betimsel analiz kullanılmıştır. DGÖA' dan elde edilen verilerin değerlendirilmesinde betimsel istatistiksel metotlardan yararlanılmıştır. Yarı yapılandırılmış görüşmeden elde edilen bulgular, öğretmenlerin çoğunluğunun dönüşüm geometrisi alt öğrenme alanının sadece sekizinci sınıfta yer almasını ve dönme hareketinin müfredattan tamamen çıkarılmasını olumlu karşıladığını ancak programda konu için öngörülen süreyi yetersiz bulduklarını ortaya koymuştur. DGÖA'dan elde edilen bulgular ise öğretmenlerin dönüșüm geometrisine yönelik bilgi düzeylerinin düşük düzeyde olduğunu göstermektedir. Öğretmenlerin büyük bir kısmının dönme dönüșümü ile ilgili sorularda ki başarısızlıkları üzerinde düşünülmesi gereken bir konudur. $\mathrm{Bu}$ nedenle müfredat yenileme çalışmalarına paralel olarak öğretmenlerin konu alan bilgisine hâkim olma durumunu tespit çalışmalarının yapılması önemlidir.

Anahtar sözcükler: Dönüşüm geometrisi, program değişikliği, öğretmen görüşleri, öğretmen bilgi düzeyi

\begin{abstract}
The aim of this study is to examine the views of mathematics teachers about the changes made in the transformation geometry sub-learning area in the secondary school mathematics curriculum renewed in 2018 and to determine their knowledge levels in this subject. The study, in which the descriptive survey model is used, is composed of twenty mathematics teachers whose attendance is in four state secondary schools. Semi-structured interview form was used to determine the thoughts of the teacher about the program change on the transformation geometry and in order to examine the knowledge levels of teachers, a transformation geometry measuring tool (TGMT) was used. There are 4 questions about reflection and rotation transformations in this measuring tool. Findings showed that the views of the majority of teachers related the program change in the transformation geometry are generally positive. According to the findings obtained, the teachers are generally satisfied with the fact that the transformation geometry is only in the eighth grade and that the rotation movement is completely removed from the curriculum. But according to the teachers, the duration of the course foreseen for the transformation geometry in the program is insufficient. Findings from TGMT indicate that teachers' knowledge levels are low. Especially, the failures of the majority of teachers in questions related to the rotation transformation is an issue to be considered. Therefore, it is important to carry out studies to determine teachers' subject knowledge in parallel with curriculum renewal studies.
\end{abstract}

Keywords: Transformation geometry, curriculum change, teachers' views, teacher knowledge levels

\section{Bu makaleye atıf vermek için:}

Yıldırım-Yakar, Z. (2020). Dönüşüm geometrisi alt öğrenme alanındaki program değişikliğinin uygunluğunun öğretmenler açısından incelenmesi. Trakya Eğitim Dergisi, 10(3), 881-896.

\section{Cite this article as:}

Yildirim-Yakar, Z. (2020). Investigation of the conformity of program change in transformation geometry sublearning in terms of teachers. Trakya Journal of Education, 10(3), 881-896.

${ }^{1} \mathrm{Bu}$ çalışma 18.04.2018 - 22.04.2018 tarihleri arasında düzenlenen 27.Uluslararası Eğitim Bilimleri Kongresi’nde sözlü bildiri olarak sunulmuştur.

${ }^{2}$ Dr.Öğr.Üyesi, Kahramanmaraş Sütçü İmam Üniversitesi, e posta: zuleyhayildirim@ksu.edu.tr ORCID: 0000-0002-6420-2205 


\section{EXTENDED ABSTRACT}

\section{Introduction}

It is thought that transformational geometry is linked to a wide variety of areas in academic and daily life (Boulter ve Kirby, 1994), supports the development of students' geometrical reasoning and provides opportunities for students to learn important mathematical concepts (Edwards, 1997; Hollebrands, 2003). Along with the curriculum changes in 2005 in Turkey, transformations such as reflection, translation, rotation, and translational reflection are included in the middle school mathematics curriculum, and the transformational geometry is included at each grade level in the sub-learning field. In the following years, with the regular updating of the curriculum, the class levels where the transformational geometry is involved and the content intensity has been changed. Finally, a major change has been made in the transformational geometry sub-learning in the middle school mathematics curriculum which was revised in 2018 and to be implemented at all grade levels in the 2018-2019 school year. Rotation movement that was in the 8th grade in the 2013 middle school mathematics curriculum was removed from the 2018 middle school mathematics curriculum. Reflection and translation movements that were in the 7th and 8th grades are included in the only 8th grade level in the 2018 program. In the 2013 program, the recommended time for the duration of the transformational geometry sub-learning area is thirty three hours in total but ten hours in the 2018 program.

There are many studies that show that middle school students have difficulties in learning the transformational geometry and in constructing some concepts in their minds (Glass, 2001; Illaslan, 2013; Köse, 2012; Kaplan ve Öztürk, 2014). There are also studies indicating that teacher and teacher candidates are inadequate in their knowledge of transformations (Ada and Kurtuluş, 2010; Gürbüz ve Durmuş, 2009; Hacısalihoğlu-Karadeniz, Baran, Bozkuş \& Gündüz, 2015; Harper, 2002; Law, 1991; Yenilmez ve Girit, 2013).

Considering the problems both students and teachers are experiencing in terms of transformation geometry, it can be thought that the source of the problems is about the abstract structure of the subject, the intensity of the content in the program and the inadequacy of the teachers' subject knowledge. However, there are very few studies investigating teachers' opinions on transformational geometry sublearning as they are included in the curriculum, the problems they have experienced in teaching the subject and subject qualifications for transformation geometry. For this reason, in this research, it is aimed to determine the teachers' thoughts related to the program change on the transformation geometry and knowledge levels about transformation geometry.

\section{Method}

The study, in which the descriptive survey model is used, is composed of twenty mathematics teachers whose attendance is in four state secondary schools. Semi-structured interview form was used to determine the thoughts of the teacher about the program change on the transformation geometry and in order to examine the knowledge levels of teachers, a transformation geometry test was used. The interview form developed by the researcher after the literature review was made consists of three open ended questions. Expert opinion has been consulted for the content validity of the semi-structured interview form. Descriptive analysis was used in the analysis of the data obtained from the semistructured interview form. In order to examine the knowledge levels of teachers, a transformation geometry test (TGT) consisting of 4 open-ended questions was used as a measurement tool in the study. Questions in measurement tool were directly taken from a scale consisting of forty differently structured problems on this subject in the literature. The obtained data were analyzed by using descriptive statistical methods.

\section{Findings}

According to the findings obtained, while $57,9 \%$ of the teachers think that reflection and translation issues are only the 8 th grade is an appropriate change, $31.6 \%$ of them think that this change is negative. $10,5 \%$ of the teachers think that the changes are made are partly positive. About the reduction of duration of the course of reflection and translation issues in the 2018 program compared to the 2013 program, $52,6 \%$ of the teachers think that duration of transformational geometry lesson is insufficient and $47,4 \%$ of the teachers think that the course duration of reflection and translation is sufficient. $57,9 \%$ 
of the teachers think positively about the removal of rotation issue from the 2018 middle school mathematics curriculum while $42,1 \%$ of the teachers think negatively.

Findings from TGMT indicate that $66,7 \%$ of the teachers could draw the reflection of the figure according to the oblique line of symmetry and $72,2 \%$ of them could determine whether the given figures were reflection of each other. Only $44,4 \%$ of the teachers were able to succeed in rotating the figure according to the rotation angle and the rotation center given outside of the figure. It was seen that the teachers had the greatest difficulty in finding the rotation center and only $22,2 \%$ of the teachers found the rotation center correctly. It was clearly that the teachers had problems in reflection and especially rotation issues.

\section{Discussion and Conclusion}

According to the findings obtained, the teachers are generally satisfied with the fact that the transformation geometry is only in the eighth grade and that the rotation movement is completely removed from the curriculum. But according to the teachers, the duration of the course foreseen for the transformation geometry in the program is insufficient. Findings from TGMT indicate that teachers' knowledge levels are low. The fact that the teachers have a very serious lack of knowledge in particular about rotation shows that one of the sources of the problems that students have experienced in the transformational geometry is the inadequacy of the teachers. For this reason, in parallel with the curriculum renewal studies, teachers should be judged on the curriculum content and the necessary support should be provided by specialists in matters where teachers are inadequate.

\section{Gİiș}

Bugüne kadar kurulan her geometrik yapıda bazı dönüşümler altında değişmeyen özellikler göze çarpmış ve bunun sonucu olarak her geometrik yapıya bir dönüşüm grubu eşlik ettirilmeye çalışılmıştır (Dönmez, 2002). Değişmeden kalabilen farklı özellikleriyle birçok dönüşüm grubu vardır: Topolojik, projektif, afin, benzerlik ve öklidyen. Ortaokul matematik öğretim programında dönüşüm geometrisi alt öğrenme alanında yer verilen öteleme, yansıma ve dönme dönüşümleri öklid geometrisinin bir parçasıdır ve bu dönüşümler düzlemdeki bütün noktaların ilgili mesafelerini ve açılarını korumaktadır(Yanik \& Flores, 2009).

Matematik eğitimcileri tarafından dönüşümlerin öğretiminin ve anlaşılmasının önemi üzerine yapılan vurgu yakın zamandan itibaren giderek artmıştır (Jones, 2002; Knuchel, 2004; Yanik \& Flores, 2009). Dönüşüm geometrisinin öğretiminin önemli bulunmasının başlıca nedenlerinden biri olarak geometrik yapılar, sanat, mimari, elektronik, coğrafya, navigasyon gibi akademik ve günlük hayatta çok çeşitli alanlarla bağlantısı düşünülebilir (Boulter \& Kirby, 1994; Knuchel, 2004). Ayrıca öğrencilere yaratıcı düşüncenin kapılarını açabilecek özellikleri olduğu (Duatepe \& Ersoy, 2003), öğrencilerin geometrik akıl yürütme ve uzamsal düşünmelerinin gelişimini desteklediği, matematiğin bağlantılı bir disiplin olduğunun fark edilebileceği bir içerik sunduğu ve öğrencilere fonksiyon gibi önemli matematiksel kavramları öğrenmelerinde firsatlar sağladığı (Edwards, 1997; Hollebrands, 2003; Peterson, 1973) düşünülmektedir. Carroll (1998)' e göre öğrencilerin sekizinci sınıfın sonuna kadar dönüşüm geometrisinde geliştirecekleri bilgi ve düşünceler, ortaöğretimde üst düzey matematik konularında mantık yürütebilmelerinde ve başarılı olmalarında belirleyicidir.

Türkiye'de 2005 yılında yapılan müfredat değişikliği ile birlikte yansıma, öteleme, dönme ve ötelemeli yansıma gibi dönüşümlerin yer aldığı dönüşüm geometrisi alt öğrenme alanı ortaokul matematik öğretim programına (OMÖP) dâhil edilerek her sınıf düzeyinde yer verilmiştir. İlerleyen yıllarda öğretim programının belli aralıklarla güncellenmesiyle birlikte dönüşüm geometrisinin yer aldığ1 sınıf düzeylerinde ve içerik yoğunluğunda değişikliğe gidilmiştir. Tablo 1'de 2013 y1lı OMÖP ve son olarak revize edilen 2018 OMÖP'ye ait dönüşüm geometrisi alt öğrenme alanı bilgileri verilmiştir. Araştırmada yenilenen program “2018 programı” olarak ifade edilmiştir. 
Tablo 1

2013 ve 2018 OMÖP'de dönüşüm geometrisi alt ögrenme alanı kazanımlarının ve öngörülen ders süresinin sınıflara göre dağılımı

\begin{tabular}{|c|c|c|c|}
\hline & Sinıf & Kazanımlar & $\begin{array}{l}\text { Ders } \\
\text { Saati }\end{array}$ \\
\hline \multirow{5}{*}{$\sum_{\substack{0 \\
0 \\
0}}^{0}$} & 7. sinif & $\begin{array}{l}\text {-Düzlemsel şekilleri karşılaştırarak eş olup olmadıklarını belirler ve bir şekle eş } \\
\text { şekiller oluşturur. } \\
\text {-Düzlemde nokta, doğru parçası ve diğer şekillerin öteleme altındaki görüntülerini } \\
\text { çizer. } \\
\text {-Ötelemede şekil üzerindeki her bir noktanın aynı yön ve büyüklükte bir dönüşüme } \\
\text { tabi olduğunu ve şekil ile görüntüsünün eş olduğunu keşfeder. } \\
\text {-Düzlemde nokta, doğru parçası ve diğer şekillerin yansıma sonucu oluşan } \\
\text { görüntüsünü oluşturur. } \\
\text {-Yansımada şekil ile görüntüsü üzerinde birbirlerine karşılık gelen noktaların simetri } \\
\text { doğrusuna olan uzaklıklarının eşit ve şekil ile görüntüsünün eş olduğunu keşfeder. } \\
\text {-Düzlemsel bir şeklin ardışı ötelemeler ve yansımalar sonucunda ortaya çıan } \\
\text { görüntüsünü oluşturur. }\end{array}$ & 20 \\
\hline & & $\begin{array}{l}\text {-Nokta, doğru parçası ve diğer düzlemsel şekillerin dönme altındaki görüntülerini } \\
\text { oluşturur. }\end{array}$ & 13 \\
\hline & \multirow{3}{*}{$\begin{array}{l}8 . \\
\text { sinif }\end{array}$} & $\begin{array}{l}\text {-Dönmede şekil üzerindeki her bir noktanın bir nokta etrafında belirli bir açılla saat } \\
\text { veya tersi yönünde dönüşüme tabi olduğunu ve şekil ile görüntüsünün eş olduğunu } \\
\text { keşfeder. }\end{array}$ & \\
\hline & & $\begin{array}{l}\text {-Koordinat sisteminde bir çokgenin öteleme, eksenlerinden birine göre yansıma, } \\
\text { herhangi bir doğru boyunca öteleme ve orijin etrafında dönme altındaki görüntülerini } \\
\text { belirleyerek çizer. }\end{array}$ & \\
\hline & & $\begin{array}{l}\text {-Şekillerin en çok iki ardışık öteleme, yansıma veya dönme sonucunda ortaya çıkan } \\
\text { görüntülerini oluşturur. }\end{array}$ & \\
\hline $\begin{array}{l}\sum_{0}^{0} \\
0 \\
\stackrel{0}{0}\end{array}$ & $\begin{array}{l}8 . \\
\text { Sinıf }\end{array}$ & $\begin{array}{l}\text {-Nokta, doğru parçası ve diğer şekillerin öteleme sonucundaki görüntülerini çizer. } \\
\text {-Nokta, doğru parçası ve diğer şekillerin yansıma sonucu oluşan görüntüsünü } \\
\text { oluşturur. } \\
\text {-Çokgenlerin öteleme ve yansımalar sonucunda ortaya çıkan görüntüsünü oluşturur. }\end{array}$ & 10 \\
\hline
\end{tabular}

Tablo 1'de görüldüğü gibi 2018 programında dönüşüm geometrisi alt öğrenme alanında büyük bir değişikliğe gidilmiştir. Dönme hareketi programdan tamamen çıkarılarak yansıma ve öteleme hareketlerine yönelik kazanımlara ise sadece 8.sınıf düzeyinde yer verilmiștir. Ortaokul öğrencilerinin dönüşüm geometrisini öğrenmede zorluklar yaşadığını ve kavramları zihinlerinde yapılandırmakta güçlük çektiğini ortaya koyan bazı araştırmaların (Aktaş \&Ünlü, 2017; Clements \& Burns, 2000; Glass, 2001; İlaslan, 2013; Kaplan \& Öztürk, 2014; Köse, 2012; Yanık, 2014) sonuçları dikkate alındığında, 2018 programında dönüşüm geometrisine daha az yoğunlukta ve güçlük düzeyi azaltılarak yer verilmesi yerinde bir karar olarak düşünülebilir.

Mashingaidze (2012)' göre dönüşüm geometrisi matematik müfredatının biraz zor ve soyut kabul edilebilecek konuları arasındadır. Hem öğrencilerin hem de öğretmenlerin anlamada ciddi problemler yaşadıkları dönüşüm geometrisine genellikle ders programının sonuna doğru yer verilir. Bununla birlikte yeterli malzeme olmaması ve teknolojiden yararlanılamaması durumunda öğretimi oldukça zaman almaktadır. Bu nedenlerle dönüşüm geometrisi çoğu matematik öğretmeni tarafından ya atlanır ya da aceleyle işlenir (Keleş, 2009).

Alanyazında sadece öğrencilerin değil öğretmen ve öğretmen adaylarının dönüşümler konusunda bilgi düzeylerinin yetersiz olduğunu belirten çalışmalar da (Ada \& Kurtuluş, 2010; Al-Khateeb, 2016; Aktaş \& Ünlü, 2017; Desmond, 1997; Gürbüz \& Durmuş, 2009; Hacısalihoğlu-Karadeniz, Baran, Bozkuş \& Gündüz, 2015; Harper, 2002; Kambilombilo \& Sakala, 2015; Law, 1991; Mbusi, 2016; Son, 2006; Turgut, Yenilmez \& Anapa, 2014) bulunmaktadır. Bu çalışmalar doğrultusunda dönüşüm 
geometrisinin öğretiminde karşılaşılan sorunların kaynağı olarak; öğretim yöntemi, konunun soyut yapısı, programdaki içerik yoğunluğu görülebileceği gibi öğretmenlerin konu alanı bilgilerinin yetersizliği de üzerinde düşünülmesi gereken bir diğer husustur. Foster (2007)'in de belirttiği gibi öğretmenlerin öğretecekleri konuyu karmaşık bulması, içerik bilgisiyle ilgili zorluklar yaşamaları ve bunun sonucu olarak da öğrencilere anlamlı gelmeyecek şekilde soyut bilgilerin öğretilmeye çalışılması durumunda öğrencilerin konuyu kavramaları oldukça güç hale gelir. Dolayısıyla öğrencilerin dönüşümler konusunda yaşadıkları zorluklar bir yönüyle de öğretmenlerin kavram yanılgılarıyla doğrudan bağlantılıdır (Zavlavsky, 1994). Bu nedenle öğrencileri konu edinen çalışmaların yanı sıra öğretim programlarının esas uygulayıcıları olan öğretmenlerin öğretecekleri konulara ilişkin olarak yaşadıkları sorunların çok yönlü olarak ele alındığı çalışmaların yapılması da eğitimde yaşanan problemlerin daha doğru tespit edilmesinde etkili olacaktır.

Yurt içinde konuya ilişkin yapılmış çalışmalar incelendiğinde dönüşüm geometrisinin öğretim programında yer alma şekline yönelik öğretmenlerin görüşlerini, konunun öğretiminde yaşadıkları sorunları veya bilgi düzeylerini araştıran çalışmaların (Gürbüz \& Durmuş, 2009; İlaslan, 2013; Yenilmez \& Girit, 2013) sınırlı sayıda olduğu görülmüsştür. Ayrıca son olarak güncellenen 2018 OMÖP'de dönüşüm geometrisi alt öğrenme alanında yapılan değişikliklerle ilgili olarak öğretmenlerin görüşlerini inceleyen çalışmaya rastlanmamıştır. Bu anlamda dönüşüm geometrisi konusunda yapılan 2018 program değişikliğiyle ilgili öğretmenlerin düşüncelerini ve bilgi düzeylerini konu edinen bu çalışma ilk olma niteliğini taşımaktadır. Öğretmenlerin dönüşüm geometrisi alt öğrenme alanında yapılan değişikliklere ilişkin görüşlerinin ve bilgi düzeylerinin incelenmesi program değişikliğinin uygunluğu noktasında fikir verebilir. Ayrıca bu çalışmanın, öğretmenlerin bilgi düzeyleri ile ilgili bilgi verecek olması nedeniyle, hizmet içi öğretmenlerle ilgili yürütülmesi gereken çalışmalara da katkıda bulunacağ 1 düşünülmektedir. Bu doğrultuda araştırmada şu sorulara yanıt aranmıştır:

•İlköğretim matematik öğretmenlerinin 2018 y1lında güncellenen ortaokul matematik öğretim programında dönüşüm geometrisi alt öğrenme alanında yapılan değişikliklere ilişkin görüşleri nelerdir?

- Öğretmenlerin dönüşüm geometrisi konusundaki bilgi düzeyleri nedir?

\section{YÖNTEM}

\subsection{Araştırmanın Modeli}

2018 OMÖP'de dönüşüm geometrisi alt öğrenme alanında yapılan değişikliğe ilişkin öğretmenlerin görüşlerinin ve öğretmenlerin dönüşüm geometrisine yönelik bilgi düzeylerinin incelendiği bu araştırma tarama modeline dayalı olan betimsel bir çalışmadır. Tarama türünde yapılan araştırmalar sayesinde bir konuya ilişkin olarak katılımcıların görüşleri, tutum, bilgi, beceri vb. özellikleri belirlenebilir (Büyüköztürk, Kılıç-Çakmak, Akgün, Karadeniz \& Demirel, 2016).

\subsection{Araştırmanın Katılımcıları}

Araştırma, Kahramanmaraş ili merkez ilçelerinde bulunan dört devlet ortaokulunda görev yapan yirmi ilköğretim matematik öğretmeninin katılımıyla gerçekleştirilmiştir. Araştırmanın katılımc1ları uygun örnekleme yöntemiyle belirlenmiştir. Uygun örnekleme yönteminde araştırmac1 ihtiyaç duyduğu sayıda katılımcıya ulaşana kadar en ulaşılabilir olan yanıtlayıcılar üzerinde çalışmaya başlar (Büyüköztürk vd., 2016). Öğretmenlerden iki tanesi kendisiyle görüşme yapılmasını kabul etmesine rağmen bilgi düzeylerini belirlemek için hazırlanan dönüşüm geometrisi ölçme aracını (DGÖA) cevaplamak istememiştir. Bir öğretmen ise görüşmeye katılmayarak sadece DGÖA'y1 cevaplamıştır. Dolayısıyla 19 öğretmen ile görüşme yapılabilmiş ve 18 öğretmene DGÖA uygulanabilmiştir. Katılımcılardan elde edilen bilgiler aktarılırken gerçek isimleri yerine kodlar kullanılmıştır. Araştırmaya gönüllü olarak katılan öğretmenlere ait bazı tanımlayıcı bilgiler aşağıdaki gibidir: 
Tablo 2

Araştırmaya katılan öğretmenleri tanımlayıcı bilgiler

\begin{tabular}{c|cccccc}
\hline & \multicolumn{3}{c}{ Cinsiyet } & \multicolumn{4}{c}{ Mesleki kıdem yılı } \\
\cline { 2 - 7 } & Bay & Bayan & $\mathbf{1 - 5}$ & $\mathbf{6 - 1 0}$ & $\mathbf{1 1 - 1 5}$ & $\mathbf{1 6 - 2 0}$ \\
\hline $\mathbf{f}$ & 9 & 11 & 2 & 6 & 7 & 5 \\
\hline $\boldsymbol{\%}$ & 45 & 55 & 10 & 30 & 35 & 25 \\
\hline
\end{tabular}

\subsection{Verilerin Toplanması ve Analizi}

Araştırmada veri toplama aracı olarak yarı yapılandırılmış görüşme formu ve Dönüşüm Geometrisi Ölçme Aracı (DGÖA) testi kullanılmıştır. Yarı yapılandırılmış görüşmeler görüşülene kendini iyi ifade etme olanağı sunması ve gerektiğinde derinlemesine bilgi sağlaması gibi avantajları (Büyüköztürk vd., 2016) nedeniyle tercih edilmiştir. Alan yazın taraması yapıldıktan sonra araştırmacı tarafından hazırlanan görüşme formu üç açık uçlu sorudan oluşmaktadır. Yarı yapılandırılmış görüşme formunun kapsam geçerliğini sağlamak için uzman görüşüne başvurulmuştur. Ayrıca soruların açık ve anlaşı1ır olup olmadığını belirlemek için iki ilköğretim matematik öğretmeni ile ön görüşme yapılmış ve elde edilen cevaplar doğrultusunda soruların anlaşılır olduğuna karar verilmiştir. Araştırmanın geçerliğini sağlamak için görüşmeler yansız bir şekilde yürütülmüştür. Görüşmeler ses kaydına alınarak daha sonra yazılı metin haline dönüştürülmüştür.

DGÖA'da yansıma ve dönme konularıyla ilgili 4 açık uçlu soru yer almaktadır. Yapılan araştırmalarda (Glass, 2001; Xistouri \& Pitta-Pantazi, 2011) ötelemenin en az sıkıntı yaşanan konu olduğu göz önünde bulundurularak DGÖA'da öteleme sorusuna yer verilmemiştir. DGÖA'da yer alan dört soru, Dixcon (1995) tarafından ilköğretim öğrencilerinin yansıma ve dönme dönüşümü becerilerini belirlemek üzerine geliştirilen bir testten olduğu gibi alınmıştır. 1.soru "bir şeklin simetri eksenine göre yansımasını çizme", 2.soru "iki şeklin birbirinin yansıması olup olmadığını belirleme ve eğer yansıması ise simetri eksenini çizme", 3.soru "verilen şeklin dönme hareketi sonucundaki görüntüsünü çizme", 4.soru ise "dönme hareketinin merkezini belirlemeye" yöneliktir. DGÖA'da yer alan soruların öğretmenlerin yansıma ve dönme dönüşümüne yönelik bilgi düzeylerinin belirlenmesinde kullanılabileceği matematik eğitimcisi olan bir uzman ve 2 ilköğretim matematik öğretmeni tarafindan belirlenmiştir.

Yarı yapılandırılmış görüşme formundan elde edilen verilerin analizinde betimsel analiz kullanılmıştır. Elde edilen veriler daha önceden belirlenen temalara göre özetlenerek yorumlanmıştır. DGÖA'da elde edilen veriler de betimsel istatistiksel metotlardan yararlanılarak değerlendirilmiştir. Öğretmenler tarafindan verilen cevaplar incelenerek doğru, yanlış ve boş cevapların frekans ve yüzde oranı değerleri belirlenmiştir.

\section{BULGULAR}

\section{1. Öğretmenlerin 2018 Programında Dönüşüm Geometrisi Alt Öğrenme Alanında Yapılan Değişikliklere İlişkin Görüşleri}

Araştırmanın bu bölümünde yarı yapılandırılmış görüşmelerden elde edilen bulgular, belirlenen temalara göre öğretmenlerin görüşlerinden doğrudan alıntılar yapılarak özetlenmiştir.

"Yansıma ve öteleme konularına sadece 8.sinıfta yer verilmesine ilişkin görüşler" temasına ait bulgular

Araştırmada öğretmenlere "2013 programında 7.sınıfta ve 8.sınıfta yer alan yansıma ve öteleme konularına 2018 programında sadece 8.sınıfta yer verilmesini nasıl değerlendiriyorsunuz?" sorusu yöneltilmiş ve verdikleri cevaplara göre öğretmenlerin dağılımı Tablo 3’te verilmiştir. 
Tablo 3

Yansima ve öteleme konularina sadece 8.sinifta yer verilmesi

\begin{tabular}{lcc}
\hline Alt temalar & Öğretmen Sayısı & Yüzde (\%) \\
\hline Olumlu karşılıyorum & 11 & 57,9 \\
\hline Olumsuz karşılıyorum & 6 & 31,6 \\
\hline Kismen olumlu buluyorum & 2 & 10,5 \\
\hline
\end{tabular}

Tablo 3'e göre öğretmenlerin çoğunluğu $(\% 57,9)$ yansıma ve öteleme konularına sadece 8 .sinıfta yer verilmesinin yerinde bir değişiklik olduğunu düşünürken \%31,6's1 bu değişikliğe olumsuz bakmaktadır. Öğretmenlerin \%10,5 i ise yapılan değişikliğin kısmen olumlu olduğunu düşünmektedir.

Olumlu görüş bildiren bazı öğretmenlerin görüşlerinden alınan birebir alıntılar şöyledir: Ö2: "Çocuklar biraz daha geliştikleri için konuyu daha iyi anlayacaklarını düşünüyorum. Yaptığımız denemelerde en çok zorlandıkları konulardandı. Öteleme daha anlaşılırdı ama yansımada oldukça zorlanıyorlardı." Ö8: "Konu yoğunluğu 7' lerde çok fazlaydı onun azaltılması açısından iyi olmuş. Yansıma ve öteleme konuları 7.sınıf seviyesine uygundu ama 8'e başladıklarında zaten 7 de yansımada ötelemede şunları yapmıştık diye tekrar ediyorduk. 8'de koordinat sistemini üzerine koyuyorduk." Ö10: "7.sınıfta ötelemede sıkıntı olmuyordu ama özellikle yansımayı görebilmek bazı öğrenciler için zor oluyordu." Ö12: "Hazır bulunuşlukları açısından 8'de olması daha uygun. Anlamada bazen zorlanabiliyorlardı 8 ' de daha iyi anlıyorlar.7'de zemin oluşturuyordu diyeceğim ama öğrenciler tekrar yapmadığ 1 ve 8'e gelirken konuyu unuttuğu için sadece 8.sınıf yeterli."

Olumsuz görüş bildiren öğretmenlerden bazılarının ifadeleri ise şöyledir: Ö11: "Birden 8' de vermek ağır olur diye düşünüyorum. 7.sınıfta yansımanın bir simetriden ibaret olduğu giriş olarak verilebilir. Sağa sola yukarı aşağı öteleme hareketleri de verilebilir. Yani 7 de bir giriş yapıp tekrar 8 de detaylı işlenmesi daha mantıklı." Ö13: "Bu konular genellikle öğrencilerin zorlandıkları konulardı. 7.sınıfta kısa bir giriş yapıldıktan sonra 8.sınıfta görülmesi taraftarıyım. 7.sınıfta son haftada olsa çok ayrıntıya girilmeden genel hatlarıyla önbilgiler verilebilirdi... Çünkü 8.sınıfta sınav çocukları oldukları için daha stres altında oluyorlar önbilgi sahibi olsalardı daha iyiydi." Ö17: "Yansıma ve ötelemenin hem 7 de hem de 8 de verilmesi gereken bir konu olduğunu düşünüyorum. Çünkü analitik zekâyı geliştiren bir konu. 7.sınıfta yansıma ve ötelemeyi çocukların anlamasında zaten sıkıntı yok. 7.sınfta noktanın, doğrunun analitik düzlemdeki yerinin incelenmesi verildikten sonra 8.sınıfta daha kapsayıcı bilgiler verilirse hiç sıkıntı olmazdı."

Yapılan değişikliği kısmen olumlu karşılayan iki öğretmen ise görüşlerini şöyle ifade etmişlerdir: Ö5: "8.sınıfa aktarılması iyi ancak 8.sınıftan kaldırılması da söz konusu olabilirdi diye düşünüyorum. Özellikle geometrik şekillerin yansıtılmasında ve simetri ekseni dikey yatay değil de eğik verildiğinde 8.sınıfta da çok zorlanıyorlar." Ö14: "Bu konunun bilimsel tarafını göremiyorum. Sadece bir dikkat ve özel kabiliyet gerektiren bir konu olarak düşünüyorum. Konunun 7.sınıftan alınması iyi bir adım 8.sınıftan da çıkarılsa bence daha da iyi olurdu."

"Yansıma ve öteleme konularına ait kazanımlara ayrılan ders süresinin azaltılmasına ilişkin görüşler" temasina ait bulgular

Öğretmenlerin "2018 programında yansıma ve öteleme konularına ait kazanımlara ayrılan ders süresinin 2013 programına kıyasla büyük oranda azaltılmasıyla ilgili ne düşünüyorsunuz? Sizce öngörülen süre yeterli mi?” sorusuna verdikleri yanıtların dağılımı Tablo 4' te verilmiştir.

Tablo 4

Yansıma ve öteleme konuları için programda öngörülen süre

\begin{tabular}{lcc}
\hline Alt temalar & Öğretmen Sayısı & Yüzde (\%) \\
\hline Yeterli buluyorum & 8 & 42,1 \\
\hline Yetersiz buluyorum & 11 & 57,9 \\
\hline
\end{tabular}


Tablo 4 incelendiğinde öğretmenlerin \%57,9'sinin 8.sinıfta yansıma ve öteleme konularına ayrılan ders süresini yeterli bulmadıkları, $\% 42,1$ inin ise yeterli bulduğu görülmektedir. Sürenin yetersiz olduğu yönünde görüş bildiren öğretmenlerden bazılarının ifadeleri şöyledir: Ö2: “...tamam kazanım sayısı azalmış ama süre daha fazla olmalıydı. Çünkü çocukların bu konuları uygulamaya dönük öğrenmesi gerekir.” Ö3: “...8.sınıfta ilk kez görecekleri için süre yeterli olmayabilir. Konunun içeriği daraltıldı evet. Süre anlatımda bizim için yetebilir ama konu soyut bir konu olduğu için birçok öğrenci zorlanabilir." Ö17: "Konu soyut bir konu olduğundan anlaş1lması güçleşecek. Soyut konulu bir dersi işlerken materyal kullanmaya özen gösteriyoruz. Materyal kullanılan derslerde de bu süre çok uzuyor. Kalabalık sınıflarda vaktimizi daha çok alıyor. Yani yarı yarıya azalmış bakarsanız ders yüzdesinin en az \%12 olması lazımdı." Ö19: "10 ders saati bence çok yetersiz. Özellikle çokgenlerin öteleme ve yansımasında çocuklar zorlanıyorlar. Zaten koordinatı tekrarlamak biraz zamanımızı alıyor ki bir de bunları koordinat üzerinde gösterdiğimizi düşünürsek süre yeterli değil.”

2018 programında yansıma ve öteleme konuları için öngörülen sürenin yeterli olduğunu düşünen öğretmenlerden birkaçının ifadeleri ise şöyledir: Ö8: "Diğer konulara o zaman yoğunluk verildi. Diğer konularda da anlaşılmada sıkıntı yaşanıyordu. Yansıma ve öteleme konuları biraz daha sadeleştirilmiş bu kadar sürede anlaşılabilir." Ö7: "Bence gayet yerinde olmuş. Bu sürede daha derine girmeden yüzeysel olarak anlatılıp en azından daha fazla kavram yanılgisına sebep vermeden konunun kazandırılması sağlanabilir." Ö: "kazanım sayısı da azaltıldığı için ders süresi bu kazanımları vermek için yeterli."

\section{“Dönme konusunun 2018 programından çıkarılmasına ilişkin görüşler” temasına ait bulgular}

"2013 programında 8.sınıfta yer alan dönme konusunun 2018 programından çıkarılmasını nasıl karşıllyorsunuz?" şeklindeki soruya öğretmenlerin verdikleri yanıtların belirlenen alt temalara göre dağılımı Tablo 5'te verilmiştir.

Tablo 5

Dönme konusunun 2018 programından çıkarılması

\begin{tabular}{lcc}
\hline Alt temalar & Öğretmen Sayısı & Yüzde (\%) \\
\hline Olumlu karşılıyorum & 11 & 57,9 \\
\hline Olumsuz karşıllyorum & 8 & 42,1 \\
\hline
\end{tabular}

Tablo 5 'e göre dönme konusunun 2018 ortaokul matematik öğretim programından çıkarılmasını öğretmenlerin $\% 57,9$ u olumlu, $\% 42,1 \mathrm{i}$ ise olumsuz olarak değerlendirmiştir. Olumlu yönde görüş bildiren öğretmenlerden bazılarının ifadeleri şöyledir: Ö2: "Çok yerinde olmuş. 8.sınıflarda en çok zorlandıkları konulardan biri dönme. Uygulamaya dökmemiz oldukça zor oluyordu. Ne kadar da somutlaştırmaya çalışsak soyut olarak kalıyordu, anlamakta zorlanıyorlardı." Ö4: "İyi olmuş. Bizim anlattığımız 8.sınıf konusu dönme zaten incelerseniz görürsünüz aynı şekilde lisede geometri dersinde de anlatılıyor. Konu, seviyeleri açısından soyut kalıyordu. Öğrencinin \%40'1 45'i 50'si anlıyor gibiydi geri kalanı zorluk çekiyordu." Ö11: "Dönme konusu gerçekten çocukların seviyesinin üzerinde bir konu. Somutlaştırmak adına sıkıntı yaşıyorduk. Çocuk mesela $90^{\circ}, 180^{\circ}$ dönmeyi tam kavrayamayabiliyordu."Ö18: "Ortaokul seviyesinde yansıma ve öteleme de sıkıntı yaşanmıyordu ama anlatırken dönme de zorlandıklarını gözlemliyordum. Oradaki dönüşümdeki formülleri ezberlemeleri gerekiyordu. Ama tabi ki çabalayanlar bir şekilde öğreniyordu. Ama seviyelerine uygun değildi bence.”

Dönme konusunun müfredattan çıkarılmasını doğru bulmayan öğretmenlerden birkaçının ifadeleri şöyledir: Ö8: "Keşke kalsaydı. Yani belli şekillerde, koordinat sistemi olarak değil de dönüp dönmediğini, ne kadar döndüğünü belirleme olarak kalabilirdi bir kazanım şeklinde. Çocuk liseye geçtiğinde koordinat sisteminde dönme direk karşısına çıkacak kavraması zor olacak diye düşünüyorum." Ö16: "Lisede karşılarına çıkacağı için belki daha basitçe ama kesinlikle dönme hareketi verilmeliydi. Uzamsal zekâlarının da gelişmemesine neden olacak. Mesela trigonometri konusunun çıkarılmasında da aynı şeyi düşünüyordum. Çocuklar 90 ile 180 ile başlamak zorunda değiller ama bir dönme hareketini bilmeli." Ö17: "Dönme konusunu anlattıktan sonra kazanım değerlendirmesini 
düşünme üzerinde ele alıyoruz genelde. Bu çocuğun zekâsını pozitif yönde etkiliyor. Öğrenci dönmeyi hayal edebilmeli, düşünebilmeli. Çoğu konumuz basite indirgendi zaten bence bu konu kalmalıydı.”

\section{2. Öğretmenlerin Dönüşüm Geometrisi Konusunda Bilgi Düzeylerine İlişsin Bulgular}

Bu bölümde DGÖA'nde yer alan her bir soruya verilen yanıtların belirli kategorilere göre frekans ve yüzde dağılımı incelenmiştir. Ayrıca öğretmenlerin yanıtlarından örnekler verilmiştir.

Tablo 6

1. soruya ilişkin verilen yanıtların frekans ve yüzdeleri

\begin{tabular}{llccccc}
\hline \multirow{2}{*}{ Sorunun içeriği } & \multicolumn{2}{c}{ Doğru cevap } & \multicolumn{2}{c}{ Yanlış cevap } & \multicolumn{2}{c}{ Boş } \\
\cline { 2 - 6 } & $\mathbf{f}$ & $\boldsymbol{f}$ & $\mathbf{f}$ & $\boldsymbol{\%}$ & $\mathbf{f}$ & $\boldsymbol{\%}$ \\
\hline $\begin{array}{l}\text { Verilen bir şeklin eğik konumdaki simetri } \\
\text { eksenine göre yansımasını çizme }\end{array}$ & 12 & 66,7 & 6 & 33,3 & - & - \\
\hline
\end{tabular}

Tablo 6'ya göre öğretmenlerin eğik konumdaki bir simetri eksenine göre yansıma çizebilmede gösterdikleri doğru yanıtlama yüzdesi \%66,7 iken öğretmenlerin \%33,3'ünün verilen şeklin yansımasını doğru çizemediği görülmektedir. Tablo 7'de öğretmenlerin eğik simetri eksenine göre yansıma çizimlerine ait yanıtlarından örnekler gösterilmiştir.

Tablo 7

Öğretmenlerin yanlış yanıtlarından örnekler

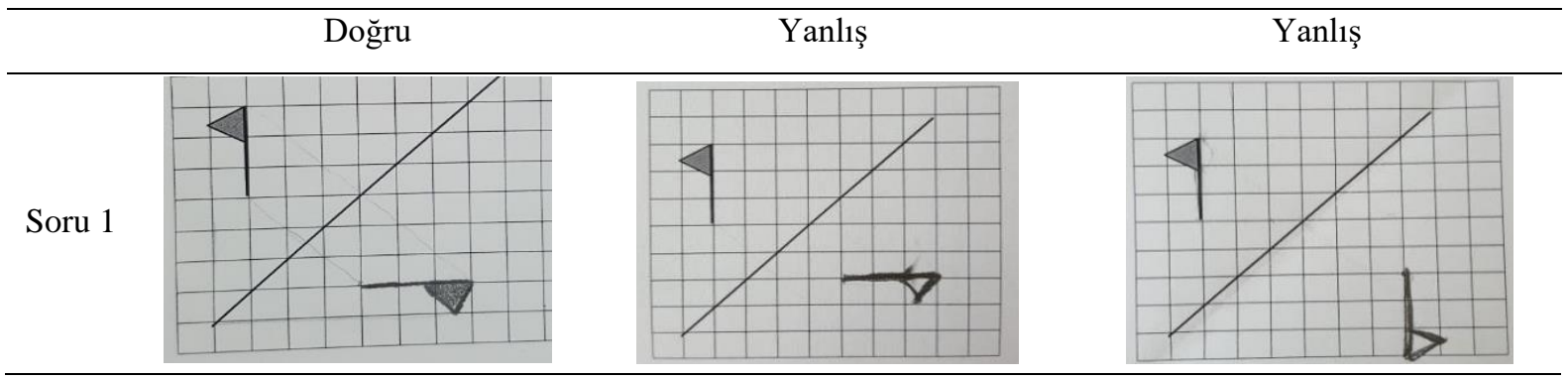

Bu sorunun doğru çözümü için, şekil üzerinde belirlenecek her bir referans noktasından verilen simetri eksenine dikmeler inilir, dikmenin simetri eksenini kestiği nokta ile referans noktasının arasındaki uzaklık kadar ilerlenerek noktanın izdüşümü tespit edilir ve son olarak izdüşüm noktaları birleştirilir. Yanlış yanıtlar incelendiğinde ise, dört öğretmenin verilen bir doğruya göre şeklin yansımasını çizerken simetrik noktaların simetri eksenine olan uzaklıklarının eşit olmasına ve simetrik noktaları birleştiren doğru parçasının simetri eksenine dik olmasına dikkat etmediği görülmüsstür. İki öğretmenin ise verilen şeklin dönme ve öteleme altındaki görüntülerini çizdiği anlaşılmıştır.

Tablo 8

2.soruya iliskkin verilen yanıtların frekans ve yüzdeleri

\begin{tabular}{llllllc}
\hline \multirow{2}{*}{ Sorunun içeriği } & \multicolumn{2}{c}{ Doğru cevap } & \multicolumn{2}{c}{ Yanlış cevap } & \multicolumn{2}{c}{ Boş } \\
\cline { 2 - 7 } & f & $\%$ & f & \% & f & $\%$ \\
\hline $\begin{array}{l}\text { Verilen şekillerin birbirinin yansıması } \\
\text { olup olmadığım belirleme. Ĕ̆er yansıma } \\
\text { var ise simetri eksenini çizme. }\end{array}$ & 13 & 72,2 & 4 & 22,2 & 1 & 5,6 \\
\hline
\end{tabular}

Tablo 8'e göre 13 öğretmen $(\% 72,2)$ 2. soruyu doğru yanıtlayarak verilen şekillerin birbirinin yansıması olmadığını belirleyebilmiştir. Soruyu yanlış cevaplayan 4 öğretmen $(\% 22,2)$ ise verilen 
şekillerin birbirinin yansıması olduğunu düşünerek simetri ekseni çizmiş, 1 öğretmen ise $(\% 5,6)$ soruyu cevaplandırmamıştır. Öğretmenlerin doğru ve yanlış yanıtlarından örnekler aşağıda Tablo 9'da verilmiştir.

Tablo 9

Öğretmenlerin 2. soruya ilişkin doğru ve yanlış yanttlarından örnekler

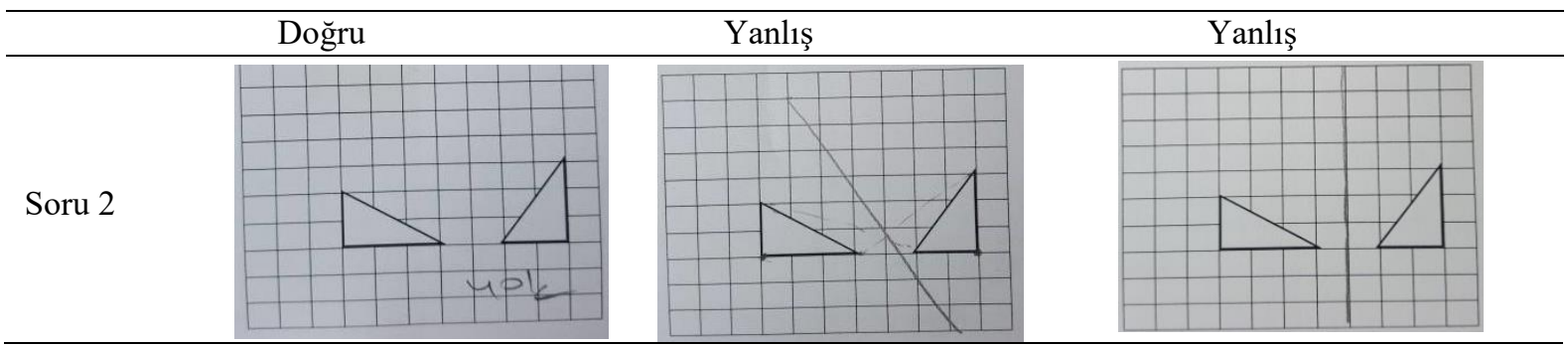

Yanlış yanıt veren 4 öğretmenin çizimleri incelendiğinde öğretmenlerin verilen şekillerin birbirinin dönme altındaki görüntüsü olduğunu göremedikleri ve verilen iki şeklin bir simetri eksenine göre birbirlerinin yansıması olabilmesi için gerekli olan bileşenlere ait bilgilerinin eksik olduğu anlaşılmıştır.

Tablo 10

3. soruya ilişkin verilen yanıtların frekans ve yüzdeleri

\begin{tabular}{lllllll}
\hline \multirow{2}{*}{ Sorunun içeriği } & \multicolumn{2}{c}{ Doğru cevap } & \multicolumn{2}{c}{ Yanlış cevap } & \multicolumn{2}{c}{ Boş } \\
\cline { 2 - 7 } & f & \% & f & \% & f & \% \\
\hline $\begin{array}{l}\text { SSekli bir dönme merkezi etrafinda saat } \\
\text { yönünde 90 döndürme }\end{array}$ & 8 & 44,4 & 9 & 50 & 1 & 5,6 \\
\hline
\end{tabular}

Tablo 10 incelendiğinde 9 öğretmenin $(\% 50)$ verilen şekli belirtilen dönme merkezi etrafinda istenen açıda döndüremediği, 8 öğretmenin $(\% 44,4)$ ise soruyu doğru yanıtladığ öğretmen $(\% 5,6)$ soruyu yanıtsız bırakmıştır. Tablo 11 'de öğretmenlerin 3. soruya ilişkin verdikleri doğru ve yanlış yanıtlardan örnekler yer almaktadır.

Tablo 11

Öğretmenlerin 3. soruya ilişkin doğru ve yanlış yanttlarından örnekler

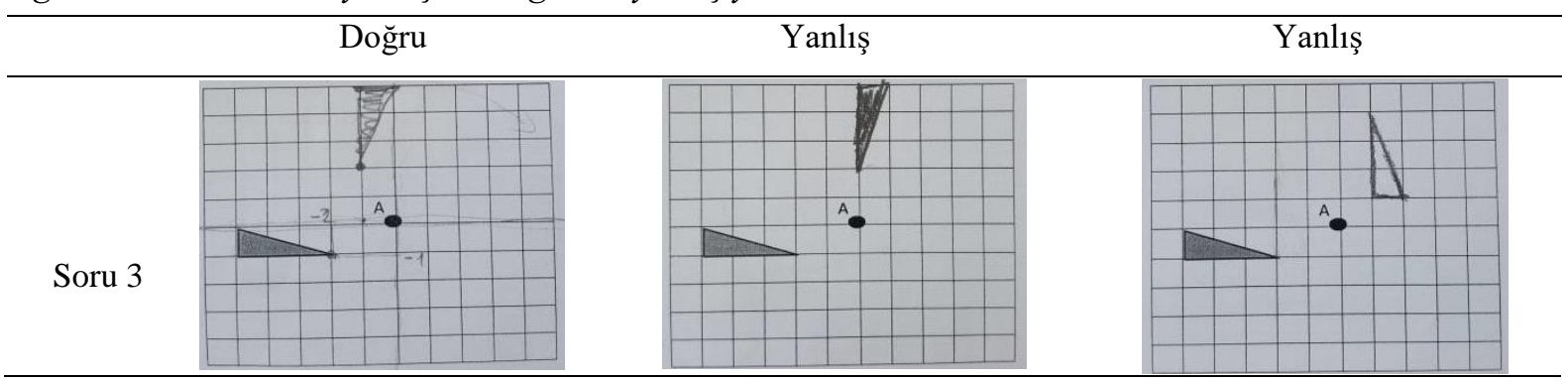

Öğretmenlerin büyük bir kısmı (\%50) verilen şekli bir nokta etrafında ve belirtilen açı kadar döndürmede başarısız olmuşlardır. Yanlış yanıt veren öğretmenlerin çoğu şeklin $90^{\circ}$ dönme hareketi altındaki duruşunu oluşturabilmelerine rağmen; şeklin her bir noktasının dönme merkezine olan uzaklıklarını sabit tutmayarak ve şeklin her bir noktası ile dönme altında oluşan görüntüsünün dönme merkezi ile oluşturduğu açının 90 olmasına dikkat etmeyerek şekli yanlış konumlandırmışlardır. 
Tablo 12

4. soruya ilişkin verilen yanıtların frekans ve yüzdeleri

\begin{tabular}{lccccccc}
\hline \multirow{2}{*}{ Sorunun içeriği } & \multicolumn{2}{c}{ Doğru cevap } & \multicolumn{2}{c}{ Yanlış cevap } & \multicolumn{2}{c}{ Boş } \\
\cline { 2 - 8 } & f & $\%$ & f & $\%$ & f & $\%$ \\
\hline $\begin{array}{l}\text { Dönme hareketinin } \\
\text { merkezini bulma }\end{array}$ & 4 & 22,2 & 13 & 72,2 & 1 & 5,6 \\
\hline
\end{tabular}

Tablo 12'ye göre öğretmenlerin büyük bir kısmı $(\% 72,2)$ dönme hareketinin merkezini yanlış belirlemiş, 1 öğretmen $(\% 5,6)$ ise soruyu yanıtsız bırakmıştır. Sadece 4 öğretmen soruyu doğru cevaplayabilmiştir. Aşağıda verilen Tablo 13'de öğretmenlerin yanıtlarından örnekler verilmiştir. Verilen yanıtlar incelendiğinde, etrafında dönme hareketi yapılan sabit noktanın belirlenmesinde büyük sıkıntılar yaşandığı görülmüsstür. Belirledikleri dönme merkezine göre, dönme hareketinin gerçekleştirildiği şekil üzerindeki her bir noktanın dönme merkezine olan uzaklığının korunmadığını ve aynı dönme açısıyla yer değiştirmediğini dikkate almamışlardır.

Tablo 13

Öğretmenlerin 4.soruya ilişkin doğru ve yanlış yanıtlarından örnekler

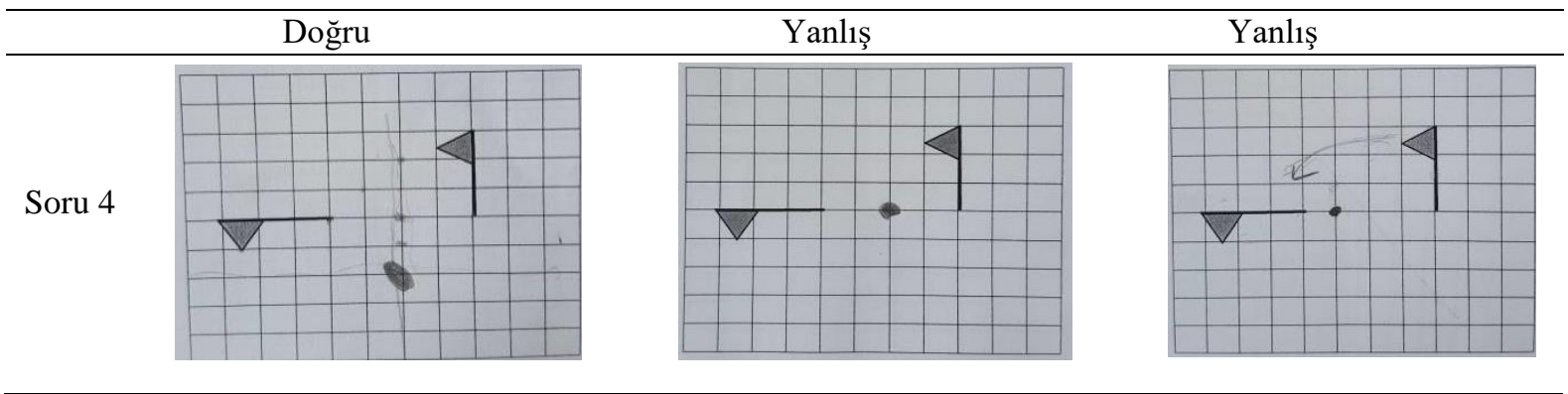

Verilen yanıtlar incelendiğinde, etrafinda dönme hareketi yapılan sabit noktanın belirlenmesinde büyük sıkıntılar yaşandığı görülmüştür. Belirledikleri dönme merkezine göre, dönme hareketinin gerçekleştirildiği şekil üzerindeki her bir noktanın dönme merkezine olan uzaklığının korunmadığını ve aynı dönme açısıyla yer değiştirmediğini dikkate almamışlardır.

\section{TARTIŞMA, SONUÇ ve ÖNERILER}

Araştırmadan elde edilen sonuçlara göre, 2013 programında 7.ve 8. sınıfta yer alan yansıma ve öteleme konularına 2018 programında sadece 8 . sınıfta yer verilmesini öğretmenlerin çoğunluğu olumlu karşılamışlardır. Bazı öğretmenler ise dönüşüm geometrisinin öğrencilerin uzamsal düşünmelerini geliştirdiğini ve ön bilgi olması açısından 7. sınıfta da yer alması gerektiğini düşünerek yapılan değiş̧ikliği olumsuz karşılamışlardır. $\mathrm{Bu}$ değişikliği olumlu karşılayan öğretmenler, dönüşüm geometrisinin soyut içerikli olmasından dolayı 7. sınıf öğrencilerinin seviyesine uygun olmaması, 7. sınıfta işlenen yansıma ve öteleme konularının 8.sınıfta tekrardan işleniyor olması, 7.sınıfta konu yoğunluğunun zaten fazla olması gibi nedenleri öne sürmüşlerdir. Ayrıca öğrencilerin ötelemeyi daha kolay anlayabildiklerini ancak yansıma ile ilgili kazanımlarda zorlandıklarını belirtmişlerdir. Literatürde öğretmenlerin bu görüşünü destekleyecek nitelikte olup yansıma konusunda yaşanan güçlükleri tespit eden bazı çalışmalar bulunmaktadır (Aktaş ve Ünlü, 2017; Bulf, 2010; Didiş \& Ubuz, 2010; Grenier, 1988; Hoyles \& Healy, 1997; Köse, 2012; Leikin, Berman \& Zaslavsky, 1997). Glass (2001) tarafından yapılan çalışmada öğrencilerin en iyi ötelemeyi, sonra yansımayı kavrayabildiği, dönmeyi ise en az somutlaştırabildikleri belirlenmiştir. Bulf (2010), 12-13 ve 13-14 yaş gruplarındaki öğrencilerin dönüşümleri tanıma durumlarını incelediği çalıșmasında, ortaokul ikinci sınıftaki 12-13 yaşındaki öğrencilerin sadece \%34,7'sinin, son sınıftaki 13-14 yaşındaki öğrencilerin ise \%55'inin bir noktaya ve bir eksene göre yansıma durumunu tanıyabildikleri sonucuna ulaşmıştır. Ayrıca ortaokulun 
sonunda öğrencilerin yansıma ile ilgili metrik özelliklere daha hâkim olduklarını ve matematiksel düşünmelerinin geliştiğini belirtmiştir. Köse (2012), 8. sınıf öğrencilerinin doğruya göre simetri bilgilerini incelediği çalışmasının sonucunda simetri konusunda çeşitli kavram yanılgılarının mevcut olduğunu görmüştür. Öğrencilerin bir şeklin simetri doğrusu ile kesişmediği durumlarda yatay veya dikey doğruya göre simetri almada başarılı oldukları ancak şeklin simetri doğrusuyla kesiştiği veya eğik simetri doğrusu kullanılan diğer tüm durumlarda kavramsal hatalar yaptıkları belirlenmiştir. Benzer şekilde Hoyles ve Healy’e (1997) göre 12 yaşındaki öğrenciler simetri ekseninin eğik verilmesi durumunda şeklin simetriğini bulmakta zorlanmaktadırlar. Aktaş ve Ünlü'nün (2017) dönüşüm geometrisiyle ilgili çalışmasında ise 8. sınıf öğrencilerinin ötelemenin yer değişrtirme hareketi olduğunu kavradıkları ancak dönüşümünün yönü ve dönüşüm altındaki pozisyon gibi konularda zorlandıkları aynı zamanda simetri ekseninin denklemini bulmada ve düzgün çokgenlerin simetri eksenlerini belirlemede hatalar yaptıkları sonucuna ulaşılmıştır.

Araştırmanın diğer bir sonucuna göre öğretmenlerin büyük bir kısmının 2018 programında dönüşüm geometrisi alt öğrenme alanıyla ilgili olarak eleştirdikleri nokta yansıma ve öteleme kazanımları için öngörülen ders süresinin 2013 programına göre azaltılmasıdır. Öğretmenlerin yine çoğunluğu, 2013 programında 8. sinıfta yer alan dönme konusunun 2018 programından tamamen çıkarılmasını yerinde bir değişiklik olarak belirtmişlerdir. Olumlu yönde görüş bildiren öğretmenler, dönme konusunun ortaokul öğrencilerinin seviyesine uygun olmadığını ve öğrencilerin anlamakta çok güçlük çektiklerini vurgulamışlardır. Dönme konusunun 2018 programından tamamen çıkarılmasını doğru bulmayan öğretmenler ise öğrencilerin öğrenmelerini kolaylaştırmak için içeriğin basitleştirilmesinin bir çözüm olabileceğini düşündüklerini ve dönme konusuna müfredatta yer verilmesinin öğrencilerin uzamsal düşünmelerinin gelişimi ve ortaöğretim geometrisi için hazırbulunuşlukları açısından önemli olduğunu açıklamışlardır. Gerek olumlu gerekse olumsuz görüş bildiren öğretmenlerin açıklamalarından 2013 programında 8. sınıfta bulunan dönme konusunun içeriğinin öğrencileri zorladığı anlaşılmaktadır. Öğretmenlerin bu görüşünü destekleyecek bir çalışmada Kaplan ve Öztürk (2014), öğrencilerin dönme açısını algılamakta ve şeklin dışında verilen bir merkeze göre belli bir açıda şekli döndürmekte zorlandıklarını ve öğrencilerin bu konuyu sadece işlemsel bilgi boyutuyla ele alarak verilen anahtar bilgileri ezberleme yoluna gittiklerini belirtmişlerdir. Aynı şekilde Aktaş ve Ünlü (2017), 8.sınıf öğrencilerinin dönme açısını bulma ve uygulamada problemler yaşadıklarını tespit etmişlerdir. Xistouri ve Pantazi (2010), ortaokul öğrencilerinin bilişsel tarz ve dönüşüm geometrisi yeteneklerini inceledikleri çalışmalarının sonucunda, öğrencilerin dönüşüm geometrisi başarı testinde en çok dönme ile ilgili sorularda zorlandıkları ve uzamsal ve nesnel imgelerle ilgili bilişsel düşüncelerinin dönüşüm geometrisi performanslarını etkilediği görülmüştür. Benzer şekilde Evbuomwan (2013), Van Hiele'nin öğrenme düzeylerini kullanarak 14-16 yaş aralığındaki öğrencilerinin dönme hareketini öğrenirken yaşadıkları zorlukları araştırdığı çalışmasında, öğrencilerin dönme dönüşümünü belirleme ve adlandırma, merkez bulma, döndürme açısı bulma ve dönme altındaki görüntüsü verilen şekli bulma konularında zorluk çektiği sonucuna ulaşmıştır.

Araştırmada genel olarak öğretmenlerin dönüşüm geometrisi ile ilgili görüşlerinden elde edilen bulgular İlaslan (2013)'ın çalışmasının bulgularıyla benzerlik göstermektedir. İlaslan (2013)'ın ortaokul matematik öğretmenleriyle yaptı̆̆ görüşmelerde katılımcılar, materyal eksikliği, öğrencilerin görselleştirme yeteneklerinin azlı̆̆ı, fiziksel mekânın ve zamanın yetersizliği gibi nedenlerle dönüşüm geometrisini öğretirken zorlandıklarını ve özellikle dönme konusunun en çok sorun yaşadıkları konu olduğunu ifade etmiş̧lerdir. Ancak Yenilmez ve Girit (2013)'in yapmış olduğu çalışmada, 2005 yılında matematik programına giren yeni konuların uygun ve gerekli olup olmadığına ilişkin olarak görüşleri alınan öğretmenlerin 17'si dönüşüm geometrisi içeriğini uygun bulduğu, 8'inin uygun bulmadığı ve 2 'sinin görüş bildirmediği açıklanmışlardır. Uygun bulmayan öğretmenler konuların çok ağır olması, okullarda araç gereç eksikliği, teknoloji ve tasarım dersinde öğretilmesi gerektiği, dönme konusunda öğrencilerin zorlanmas1 gibi sebepleri öne sürmüşlerdir.

Diğer bir amacı öğretmenlerin dönüşüm geometrisiyle ilgili bilgi düzeylerini incelemek olan araştırmada elde edilen sonuçlara göre öğretmenlerin \%66,7'si eğik simetri doğrusuna göre şeklin yansımasını çizebilmiş ve \%72,2'si iki şeklin birbirinin yansıması olup olmadığını belirleyebilmişlerdir. Şeklin dışında verilen dönme merkezine göre belirtilen açı ölçüsünde ş̧ekli döndürmede ise öğretmenlerin sadece \%44,4'ü başarılı olabilmiştir. Öğretmenlerin en büyük güçlüğü dönme hareketinin merkezini bulmada yaşadığı ve sadece \%22,2'sinin merkez noktayı belirleyebildiği 
görülmüştür. Araştırmanın sonuçlarına bakıldığında öğretmenlerin yansıma ve dönme konusunda güçlükler yaşadıkları ortadadır. Özellikle de öğretmenlerin büyük kısmının dönme ile ilgili sorulardaki başarısızlıkları üzerinde düşünülmesi gereken bir durum olarak nitelendirilebilir.

Dönüşüm geometrisinde öğretmenlerin bilgi düzeylerini ve yeterliklerini konu edinen çok sınırlı sayıda çalışma mevcuttur. Bunlardan birinde Al-Khateeb (2016), öğrencilerin geometrik kavram yanılgıları ve hataları konusunda öğretmenlerin farkındalıklarını incelemiştir. Öğrencilerin öteleme, yansıma ve dönme gibi birçok geometrik kavram yanılgılarına sahip olduğunu ancak bu konuda öğretmenlerin yetersiz olduğunu ortaya çıkarmıștır. Gürbüz ve Durmuş’un (2009) çalışmasında, yirmi beş ilköğretim matematik öğretmenine yeterlik testi uygulanmış ve dönüşüm geometrisi alt öğrenme alanının yansıma konusunda öğretmenlerin \%84'ünün, dönme konusunda ise \%68'inin yeterli olduğu sonucu elde edilmiştir. Öğretmenlerle yapılan mülakat sonucunda eski programda yansıma konusunun simetri adı altında yer alması sebebiyle, matematik programı yeni olmasına rağmen öğretmenlerin yansıma konusuna yabancı olmadıkları ifade edilmiştir. İlköğretim matematik öğretmenlerin matematik öğretim programında yer alan dönüşüm geometrisi alt öğrenme alanındaki yeterliklerinin olması gereken düzeyde olmadığı anlaşılmıştır. İlaslan'ın (2013) çalışmasında, öğretmenlerin dönüşüm geometrisi konusunda uygun eğitim ve desteği almadıkları için kendilerini yetersiz hissettikleri açıklanmıştır. Bu araştırmada ulaşılan öğretmenlerin yansıma ve özellikle de dönme konusunda bilgi eksikliği olduğu sonucu, Yenilmez ve Girit'in (2013) çalışmalarının sonuçlanyla örtüşmemektedir. Alan bilgisi yeterlilikleri hakkında matematik öğretmenleriyle gerçekleştirdikleri görüşmelerin sonucunda yansıma ve dönme konularında öğretmenlerin 13'ü kendisini tamamen yeterli, 11 'i yeterli ve 3'ü kısmen yeterli olarak nitelendirmişlerdir. Öğretmenlerin yeterliliklerinin kendileri tarafından değerlendirilmesi ise çalışmanın sınırlılığı olarak düşünülebilir.

Bu araştırmada ulaşılan öğretmenlerin yansıma ve özellikle de dönme konusunda bilgi eksikliği olduğu sonucunu destekleyecek şekilde öğretmen adayları üzerinde yürütülen çalışmalardan birinde Turgut, Yenilmez ve Anapa (2014), öğretmen adaylarının bir şeklin verilen eksene göre yansımasını çizmede çok zorluk yaşamadıklarını ancak verilen iki şeklin birbirinin yansıması olup olmadığını belirlemede ve simetri eksenini çizmede zorlandıklarını belirtmişlerdir. Öğretmen adaylarının dönme becerilerinin çok zayıf olduğunu ve genellikle dönme konusundaki hatalarının dönme merkezini, uzaklığı, verilen şekli dikkate almamaktan kaynaklandığını, dönme merkezini belirlemekte ise başarısız oldukları sonucu elde edilmiştir. Son'un (2006) çalışmasında öğretmen adaylarının bazılarının paralelkenarın simetri ekseni olduğunu düşündüğü ve simetri kavramının özelliklerini tam bilmedikleri sonucu elde edilmiştir. Yanık ve Flores'a (2009) göre dönüşüm geometrisi üzerine yapılan çalışmalar, öğretmen adaylarının geometri anlayışından yoksun olduğunu ve özellikle de dönüşüm kavramlarını anlamadıklarını göstermiştir. Mbusi (2016) öğretmen adaylarının dönüşüm geometrisine yönelik yanılgılarını van Hiele'in geometrik gelişim düzeylerine göre incelediği çalışmasında, öğretmen adaylarının çoğunun, bu konuda 2. düzeydeki geometrik akıl yürütmenin ötesine geçemediğini belirlemiştir. Law (1991), öğretmen adaylarının öteleme, yansıma ve dönme kavramlarını nasıl geliştirdiklerini ve öğrendiklerini araştırdığ 1 çalışmasında geometri derslerinde geometrik dönüşümler konusunu gören 18 öğretmen adayıyla görüşmeler gerçekleștirmiștir. Görüşmeler sırasında, öğretmen adaylarından dönüşümleri tanımlamaları ve düşüncelerini göstermek için örnekler vermeleri istenmiştir. Sonuç olarak, öğretmen adaylarının somut bir biçimde ya da soyut terimleri kullanarak öteleme, yansıma ve dönme dönüşümlerinin tanımını yapmada güçlük çektiği belirlenmiştir. Ada ve Kurtulmuş (2010)'un çalışmasının sonucunda öğretmen adaylarının dönme dönüşümünün nasıl uygulanacağını anlamadıkları, dönüşümlerin cebirsel anlamını bilmelerine rağmen bunların geometrik anlamını bilemedikleri belirlenmiştir.

Araştırmada öğretmenlerin 2018 programında dönüşüm geometrisi alt öğrenme alanında yapılan değişikliklere ilişkin görüşlerinden elde edilen sonuçlar ve eğitimin her düzeyinde öğrencilerin dönüşüm geometrisini öğrenirken yaşadıkları güçlükleri konu edinen birçok alanyazın çalışmasının bulguları değerlendirildiğinde, dönüşüm geometrisine ait kazanımların içerik yoğunluğunun azaltılarak sadece 8. sınıf'a aktarılmasının ve dönme konusunun müfredattan çıkarılmasının yerinde bir karar olduğu düşünülebilir. Ancak eğitim-öğretimde karşılaşılan sorunları çözmek için müfredatta yapılacak iyileştirmelerin yanı sıra bu müfredatı uygulayacak olan öğretmenlerinde gerekli yeterliliğe sahip olması önemlidir. Shulman'a (1987) göre sınırlı düzeyde matematik bilgisi olan öğretmenler öğretim aşamasında esnek, etkileşimli, öğrenci merkezli bir öğrenme ortamı oluşturamaz. Araştırmanın 
sonucunda ulaşılan dönüşüm geometrisinin öğretimini gerçekleştirecek öğretmenlerin çok ciddi bilgi eksikliklerinin olduğu gerçeği, öğrencilerin dönüşüm geometrisinde yaşadıkları sorunların sadece programdan kaynaklanmadığını ve sorunun bir parçasının da öğretmenlerin yetersizliği olduğunu göstermektedir. $\mathrm{Bu}$ nedenle müfredat yenileme çalışmalarına paralel olarak öğretmenlerin konu alan bilgisine hâkim olma durumunu tespit çalışmalarının yapılması ve öğretmenlerin yetersiz olduğu konularda gerekli desteğin uzmanlar tarafından verilmesi sağlanmalıdır. Literatür taramasında öğretmenlerin konu alan bilgisi düzeylerine yönelik çalışmaların yok denecek kadar az olduğu görülmüştür. Bu nedenle yapılacak araştırmalarda matematik öğretim programındaki diğer öğrenme alanlarının uygunluğu noktasında öğretmenlerin görüşlerinin alınması ve bu görüşler doğrultusunda öğretmenlerin konu yeterliliklerinin incelenmesi alana katkı sağlayacaktır.

\section{KAYNAKÇA}

Ada, T., \& Kurtuluş, A. (2010). Students' misconceptions and errors in transformation geometry. International Journal of Mathematical Education in Science and Technology, 41(7), 901-909.

Aktaş, G. S., \& Ünlü, M. (2017). Understanding of Eight Grade Students about Transformation Geometry: Perspectives on Students' Mistakes. Journal of Education and Training Studies, 5(5), 103-119.

Al-Khateeb, M. A. (2016). The extent of mathematics teacher's awareness of their students' misconceptions in learning geometrical concepts in the intermediate education stage. European Scientific Journal, ESJ, 12(31).

Boulter, D. R., \& Kirby, J. R. (1994). Identification of strategies used in solving transformational geometry problems. Journal of Educational Research, 87 (5), 298-303.

Bulf, C. (2010). The effects of the concept of symmetry on learning geometry at French Secondary School. Proceedings CERME 6, 726-735.

Büyüköztürk, Ş., Kılıç Çakmak, E., Akgün, Ö. E., Karadeniz, Ş., \& Demirel, F. (2016). Bilimsel araştırma yöntemleri. Ankara: Pegem Akademi Yayıncılık.

Carroll, W. M. (1998). Middle school students' reasoning about geometric situations. Mathematics Teaching in the Middle School, 3, 398-403.

Clements, D. H., \& Burns, B. A. (2000). Students' development of strategies for turn and angle measure. Educational Studies in Mathematics, 41(1), 31-45.

Desmond, N. S. (1997). The geometric content knowledge of prospective elementary teachers. Unpublished doctoral thesis, The University of Minnesota.

Didiş, M. G., \& Ubuz, B. (2010). Öğrencilerin simetri konusundaki anlamalarının SOLO taksonomisine gore değerlendirilmesi. 9. Matematik Sempozyumu, Trabzon, Karadeniz Teknik Üniversitesi.

Dixon, J. K. (1995). English language proficiency and spatial visualization in middle school students' construction of the concepts of reflection and rotation using the geometer's sketchpad. Unpublished doctoral dissertation, University of Florida.

Dönmez, A. (2002). Matematiğin öyküsü ve serüveni. İstanbul: Toplumsal Dönüşüm.

Duatepe, A., \& Ersoy, Y. 2003. Teknoloji destekli matematik öğretimi. [Online]: http://www.matder.org.tr adresinden 20 Eylül 2011 tarihinde indirilmiştir.

Edwards, L. D. (1997). Exploring the territory before proof: students' generalizations in a computer microworld for transformation geometry. International Journal of Computers for Mathematical Learning, 2, 187-215.

Evbuomwan, D. (2013). An investigation into the difficulties faced by form C students in the learning of transformation geometry in Lesotho secondary schools. Unpublished master's thesis, University of South Africa.

Foster, D. (2007). Making meaning in algebra: Examining students' understandings and misconceptions. Assessing mathematical proficiency, 53, 163-176. 
Glass, B. J. (2001). Students' reification of geometric transformations in the presence of multiple dynamically linked representations. Unpublished doctoral dissertation, The University of Iowa.

Grenier, D. (1988). Construction et étude du fonctionnement d'unprocessus d'enseignement de la symétrie orthogonale en sixième. Unpublished doctoral dissertation, Université Joseph Fourier.

Gürbüz, K., \& Durmuş, S. (2009). İlköğretim matematik öğretmenlerinin dönüşüm geometrisi, geometrik cisimler, örüntü ve süslemeler alt öğrenme alanlarındaki yeterlilikleri. Abant İzzet Baysal Üniversitesi Dergisi, 9(1), 1-22.

Hacısalihoğlu-Karadeniz, M., Baran, T., Bozkuş, F., \& Gündüz, N. (2015). İlköğretim matematik öğretmeni adaylarının yansıma simetrisi ile ilgili yaşadıkları zorluklar. Türk Bilgisayar ve Matematik Eğitimi Dergisi, 6(1), 117-138.

Harper, S. R. (2002). Enhancing elementary pre-service teachers' knowledge of geometric transformations. Unpublished Doctoral Dissertation, University of Virginia.

Hollebrands, K. F. (2003). High school student' understandings of geometric transformations in the context of a technological environment. Journal of Mathematical Behavior, 22, 55-72.

Hoyles, C., \& Healy, L. (1997). Unfolding meanings for reflective symmetry. International Journal of Computers for Mathematical Learning, 2(1), 27-59.

İlaslan, S. (2013). Middle school mathematics teachers' problems in teaching transformational geometry and their suggesstions for the solution of these problems. Unpublished master's thesis, Middle East Technical University, Ankara.

Jones, K. (2002). Issues in the teaching and learning geometry. In L. Haggarty (Ed.) Aspects of Teaching Secondary Mathematics: Perspectives on Practice (pp.121-139). London: Routledge Falmer.

Kambilombilo, D., \& Sakala, W. (2015). An investigation into the challenges in-service student teachers encounter in transformational geometry, "reflection and rotation". The case of Mufulira college of education. Journal of Education and Practice, 6(2), 139-149.

Kaplan, A., \& Öztürk, M. (2014). 2-8. sınıf öğrencilerinin simetri kavramını anlamaya yönelik düşünme yaklaşımlarının incelenmesi. İlköğretim Online, 13(4), 1502-1515.

Keleş, Ö. (2009). An investigation of elementary and mathematics teachers' views about the new elementary school mathematics curriculum. Master's Thesis, Middle East Technical University, Ankara, Turkey.

Knuchel, C. (2004). Teaching symmetry in the elementary curriculum. TMME, 1(1), 3-8.

Köse, N.F. (2012). İlköğretim öğrencilerinin doğruya göre simetri bilgileri. Hacettepe Üniversitesi Eğitim Fakültesi Dergisi, 42, 274-286.

Law, C. K. (1991). A genetic decomposition of geometric transformations. Unpublished doctoral dissertation, Purdue University, Indiana.

Leikin, R., Berman, A. \& Zaslavsky, O. (1997). Defining and Understanding Symmetry. In E. Pehkonen (Ed.), Proceedings of the 21st International Conference for the Psychology of Mathematics Education, (Vol. 3, pp. 192-199). Lahti, Finland.

Mashingaidze, S. (2012). The teaching of geometric (Isometric) transformations at secondary school level: what approach to use and why?. Asian Social Science, 8(15), 197.

Mbusi, N. (2016). Misconceptions and related errors displayed by pre-service foundation phase teachers in transformation geometry. International Conference on Mathematics, Science and Technology Education, 386-400.

Peterson, J. C. (1973). Informal geometry in grades 7-14. In K.B. Henderson (Ed.), Geometry in the mathematics curriculum: Thirty-sixth yearbook. (pp. 52- 91). Washington, DC: NCTM.

Shulman, Lee S. (1987). Knowledge and teaching: Foundations of the new reform. Harvard Educational Review, 57 (1), 1-22.

Son, J. (2006). Investigating preservice teachers' understanding and strategies on a student's errors of reflective symmetry. In J. Novotná,., H. Moraová, M. Krátká, \& N. Stehlíková, (Eds.). 
Proceedings 30th Conference of the International Group for the Psychology of Mathematics Education, (Vol. 5, pp. 145-152). Prague: PME.

Turgut, M., Yenilmez, K., \& Anapa, P. (2014). Symmetry and rotation skills of prospective elementary mathematics teachers. Bolema, Rio Claro (SP), 28(48), 383-402.

Xistouri, X., \& Pitta-Pantazi, D. (2011). Elementary students' transformational geometry abilities and cognitive style. In Proceedings from CERME7: The Seventh Congress of the European Society for Research in Mathematics Education. February (Vol. 11).

Yanik, B. H. \& Flores, A. (2009). Understanding rigid geometric transformations: Jeff's learning path for translation. Journal of Mathematical Behavior, 28, 41-57.

Yanik, H. B. (2014). Middle-school students' concept images of geometric translations. The Journal of Mathematical Behavior, 36, 33-50.

Yavuzsoy-Köse, N. Y. (2012). İlköğretim öğrencilerinin doğruya göre simetri alma bilgileri. Hacettepe Üniversitesi Eğitim Fakültesi Dergisi, 42, 274-286.

Yenilmez, G., \& Girit, D. (2013). İlköğretim (6-8) matematik dersi öğretim programındaki yeni alt öğrenme alanlarına ilişkin öğretmen görüşleri. Ondokuz Mayıs Üniversitesi Eğitim Fakültesi Dergisi, 32(2), 385-419.

Zavlavsky, O. (1994). Tracing students' misconceptions back to their teacher: a case of symmetry. Pythagoras, Tygervalley, South Africa, 33(1), 10-17. 